Research Article

\title{
Factors Motivating Farmers for Collective Action for Management of Irrigation System in Nepal
}

\author{
Kapil Khanal $^{1 *}$, Kalika Bahadur Adhikari ${ }^{1}$, Shiva Chandra Dhakal', \\ Santosh Marahatta ${ }^{2}$ \\ ${ }^{1}$ Department of Agricultural Economics and Agribusiness Management, Agriculture and Forestry University, \\ Chitwan, Nepal \\ ${ }^{2}$ Department of Agronomy, Agriculture and Forestry University, Chitwan, Nepal
}

Article Information
Received: 02 October 2020
Revised version received: 07 January 2021
Accepted: 10 January 2021
Published: 25 January 2021
Cite this article as:
K. Khanal et al. (2021) Int. J. Soc. Sc. Manage. 8(1):
285-291. DOI: $10.3126 / i j s s m . v 8 i 1.31748$
*Corresponding author
Kapil Khanal,
Department of Agricultural Economics and
Agribusiness Management, Agriculture and Forestry
University, Chitwan Nepal
Email: kapilkhanal46@gmail.com
Peer reviewed under authority of IJSSM
(C) 2021 IJSSM, Permits unrestricted use under the
CC-By-NC license.
OPEN 6 ACCESS
This is an open access article \& it is licensed under a
Creative Commons Attribution Non-Commercial 4.0
International
Keywor:/creativecommons.org/licenses/by-nc/4.0/)

\begin{abstract}
The study analyzed the factors motivating the farmers for collective action for the management of the Shardikhola Puranchaur Irrigation System of the Kaski district of Nepal in 2019. A cross-sectional data of 184 farmers were collected using a simple random sampling method. A logit regression was used for data analysis. Age of the household head, years of schooling of the household head, presence of fine in monetary terms, number of farmers in a branch of the irrigation system positively motivated farmers in the involvement in the group for the management of the irrigation system. Motivation among farmers for collective action for management of the irrigation system was influenced by a combination of different factors. Therefore, the proper distribution of water at different branches, binding every level of users by law and transparency in the use of the income of the irrigation system must be maintained to achieve the desired results.
\end{abstract}

Keywords: irrigation; motivation; management; irrigation; farmers

\section{Introduction}

Agriculture is the source of livelihood for $60.4 \%$ of the total population of Nepal and it contributes $26.5 \%$ of the national GDP (AITC, 2020). Nepal has 2.7 million hectares of agricultural land (Pradhan, 2012) of which only 54\% is irrigated (CBS, 2013). Farmers Managed Irrigation System

(FMIS) is the indigenous irrigation system on which the Nepalese agricultural economy was always based (Gautam, 2012). Although $70 \%$ of irrigated land areas in Nepal fall in the category of the farmer-managed irrigation system (Pradhan, 2012), the produce contributes only $40 \%$ of the 
country's food requirement (Gautam 2012). The government of Nepal had tried to improve and maintain the irrigation system by incorporating local communities in the management of the irrigation system (Dhakal et al., 2018). Irrigation systems are used all year round when the water source is perennial which is a rare case, as in most of the cases irrigation systems are used for supplementing the main crop, i.e. paddy during the rainy season (Sijapati and Paudel, 2010). Agriculture can significantly improve the economic condition of a country but to do so it is a must to improve the efficiency of water resource use. Nepalese farmers understood the importance of water resources for a long time and that's why they have developing irrigation systems at their own for increasing their agricultural production (Pradhan, 2000).

Irrigation has contributed to increasing agricultural land, productivity, made double-cropping feasible and protected from the adversity of irregular rainfall but the benefits of the irrigation system are not distributed in an equitable and equal manner throughout the world (Schoengold and Zilberman 2014). Small scale irrigation systems in underdeveloped countries have a great role in poverty reduction, increased agricultural production and enhanced food security (Sinyolo et al., 2014). Irrigated agriculture is of prime importance in Nepal to ensure food security and poverty reduction. Irrigation helps households to improve their incomes and employment increase their productivity, food availability, and grow high-value crops (Hussain and Hanjra, 2003). Asian countries have invested billions of their scarce resources on developing their irrigation sector as agriculture will always be the dominant sector contributing to GDP, employment, food security, and alleviating poverty (Sampath, 1992). There is a sharp decline in investment in irrigation infrastructures in recent decades as compared to the 1970s-1980s (Rosegrant and Svendsen, 1993). This decline in investment calls for better water resource management to maintain its sustainability.

Agency managed irrigation systems are being transformed into locally managed systems for better irrigation performance (Yoder, 1994). Individuals while using common pool resources have developed sustaining institutions by establishing commonly accepted rules and strategies and communicating with each other (Ostrom et al., 1994). There is increased dependence on water user groups as there is a transition to improved management of present projects rather than the development of new irrigation projects (Schoengold and Zilberman, 2014). Irrigation management means a multidisciplinary activity that includes farmers' participation in irrigation management for increasing productivity per unit of water used (Pradhan, 2000). The better management and allocation of water resources can be ensured by the participation of local stakeholders (Ostrom et al., 1994). Farmers managed irrigation systems are significantly contributing to rural livelihood through their evolution and dynamism and use of self-governance and cooperation (Sijapati and Paudel, 2010). The capital cost of construction of an irrigation system is very high thus to ensure the high efficiency of the irrigation system, they need to be managed by local stakeholders.

A significant amount of study has been done in the fast to explain the mechanisms of collective actions for the management of the common resources. The actions of the individuals on group activities should be monitored otherwise they would cause loss to the group by only making decisions on their self-interest (Muchara et al., 2014). Individuals agree to follow a set of rules to make other users agree to the rules when they see their upcoming benefits if other users also follow the same rules (Ostrom, 1990). This implies that proper monitoring is a must for ensuring collective actions in the management of common resources. Individuals to be rational always try to maximize their utility either they are involved in a group or not and if the group activities are not sufficiently monitored individuals tend to break the rules to maximize their utility leading to a great disharmony and disorientation in the group (Weirich, 2008). In many water user associations gradual decrease in enthusiasm for collective action for management of the irrigation system (Thapa and Scott, 2019). This study tries to understand the strategies adopted by the irrigation system water user group or the factors related to the irrigation system and its user group that determine the collective management of the irrigation system. The management quality of an irrigation system will determine its agricultural productivity, financial viability, infrastructural condition and the performance and outcome of the system (Vermillion, 2001).

\section{Materials and Methods}

\section{Study Area}

The study was conducted within the Shardikhola Puranchaur Irrigation System of Puranchaur and Bhurjungkhola locality of the Kaski district of Gandaki province of Nepal. Kaski district is located in the mid-hills of Nepal. This district was selected as the representation of the majority of the hilly region of Nepal. Kaski district is located within latitude of $28^{\circ} 16^{\prime}$ North \& longitude of $83^{\circ} 53^{\prime}$ East.

\section{Sample Size}

There were 342 farmers in the water user group of the Shardikhola Puranchaur Irrigation System. The sample size was determined using Slovin's formula at a 95\% level of confidence and a total of 184 samples were selected using the technique of simple random sampling. The sample household was the representative of the irrigation system (about 53\% representation). The study of the farmers' strength of access reflects the situation of the irrigation 
system as a whole because the sample is $53 \%$ representative of the study area.

\section{Data Collection}

Pretesting was done by presenting the interview schedule among 25 members of the study area. The necessary corrections and amendments were done before conducting the actual household survey in the interview schedule. Focus Group Discussion (FGD) and Key Informant Interview (KII) were done to validate data collected during face-to-face interviews. The household survey or field survey was conducted from November - December of 2019.

\section{Data Analysis}

Softwares as SPSS and Stata were used for data entry and analysis. Data quality was improved by working on cleaning and missing data. Descriptive statistics and a logit regression model were used to reach the desired results.

\section{Logit model}

The model used in this analysis was the logit regression model which is a dichotomous analysis model (Tourenq et al. 2001). In this study, the logit model was used to analyze the factors creating incentives for the collective actions of the irrigation system. Let $y$ be the level of trust among the farmers where high trust represents the greater desire for collective action and low represents the lower desire for collective action and $\mathrm{x}$ be the vector of factors affecting the incentives for collective actions for the management of the irrigation system (Dhakal et al., 2018).

$y=f(x, e)$, where e is the error term.

In this study, $\mathrm{y}$ which is a dependent variable is assigned a value of 1 when the family says it has high trust among the members of the irrigation system and a value of 0 when the family says it has low trust among the members of the irrigation system. The dependent and independent variables used for this study are shown in the Table 1 .

Table 1: Dependent and independent variables used for the study of factors motivating farmers for collective action for management of irrigation system.

\begin{tabular}{|c|c|c|}
\hline S.N. & Variables & Description of the variables \\
\hline 1 & LTAF & Level of trust among farmers, $1=$ High, $0=$ Small (Dependent variable) \\
\hline 2 & UR & Users rights and duties, $1=$ Well defined, $0=$ Not well defined \\
\hline 3 & FM & Fine in money, $1=$ Yes, $0=$ No \\
\hline 4 & BLM & Labour mobilization basis, $1=$ Land basis, $0=$ others \\
\hline 5 & CL & Canal lining up to the field, $1=$ Cemented, $0=$ Non cemented \\
\hline 6 & NFUR & Number of farmers using the resources, $1=$ less than $40,0=$ others \\
\hline 7 & ALTwsd & Alternative source of water available, $1=$ Yes, $0=$ No \\
\hline 8 & Coop & Access to Cooperatives, $1=$ Yes, $0=$ No \\
\hline 9 & RAT & Trainings received, $1=$ Yes, $0=$ No \\
\hline 10 & AgofHHH & Age of Household Head \\
\hline 11 & NYSHHH & Numbers of years of schooling of Household Head \\
\hline 12 & $\mathrm{SSd}$ & Social sanction, $1=$ Yes, $0=$ No \\
\hline
\end{tabular}




\section{Results and Discussions}

\section{Description of The Socioeconomic and Demographic Characteristics of The Respondents}

The descriptive statistics of the respondents are as shown in the Table $2 \& 3$. The average age of the household head $(\mathrm{HHH})$ was 56.24 years. The average income of the household from agriculture was Rs. 65444 per year. The average years of schooling of household head were 7.01 years. The average family size of the study area was 5.54 and the average number of economically active family members in the study area was 3.56. The total landholding of the household was 0.37 ha and the average area under SPIS was 0.22 ha.

Table 2: Socioeconomic and Demographic characteristics (continuous variables) of the respondents in the study area

\begin{tabular}{|l|l|}
\hline Variables & Mean value \\
\hline Age of HHH & 56.24 \\
\hline Numbers of years of schooling of HHH & 7.01 \\
\hline Total land holding in hectare & 0.37 \\
\hline Land under SPIS in hectare & 0.22 \\
\hline Family size & 5.54 \\
\hline Economically active population in HH & 3.56 \\
\hline Income from the agriculture sector & Rs. 65444 \\
\hline
\end{tabular}

Table 3: Socioeconomic and Demographic characteristics (categorical variables) of the respondents in the study area

\begin{tabular}{|c|l|l|}
\hline Variables & Frequency & Percent \\
\hline Gender of the HHH & $\mathrm{N}=184$ & 100 \\
\hline Male & 147 & 79.90 \\
\hline Female & 37 & 20.10 \\
\hline Caste of the HH & $\mathrm{N}=184$ & 100 \\
\hline Brahmin & 83 & 45.10 \\
\hline Chhetri & 11 & 6.00 \\
\hline Janajatis & 65 & 35.30 \\
\hline Dalits & 19 & 10.30 \\
\hline Others & 6 & 3.30 \\
\hline Family type & $\mathrm{N}=184$ & 100 \\
\hline Nuclear & 101 & 54.90 \\
\hline Joint & 83 & 45.10 \\
\hline Primary occupation & $\mathrm{N}=184$ & 100 \\
\hline Agriculture & 108 & 58.70 \\
\hline Business & 27 & 14.70 \\
\hline Government job & 19 & 10.30 \\
\hline Private job & 14 & 7.60 \\
\hline Abroad & 16 & 8.70 \\
\hline
\end{tabular}

The gender of the $\mathrm{HHH}$ was male in $79.90 \%$ percent of the households (HHs) and $20.10 \%$ of the HHHs were female. Brahmin was the major caste in the study area with nearly $45 \%$ of the respondents belonging to the brahmin community followed by janajatis ${ }^{1}$ at about $35 \%$. About $55 \%$ of the family in the study area were nuclear whereas the remaining $45 \%$ family were joint family. The primary occupation of $58.70 \%$ of the HHs in the study area was agriculture followed by business and government jobs.

\section{Factors Motivating Farmers for Collective Actions for The Management of The Irrigation System}

Table 4, represents the socioeconomic and physical factors affecting the motivation for farmers for collective action for the management of the irrigation system in the study area.

Table 4: Summary statistics of the variables used in the logit model

\begin{tabular}{|c|c|c|}
\hline Variables & Frequency & Percent \\
\hline User rights and duties & $\mathrm{N}=184$ & 100.00 \\
\hline Well defined & 112 & 60.87 \\
\hline Not well defined & 72 & 39.13 \\
\hline Fine in money & $\mathrm{N}=184$ & 100.00 \\
\hline Yes & 119 & 64.67 \\
\hline No & 65 & 35.33 \\
\hline Labor mobilization basis & $\mathrm{N}=184$ & 100.00 \\
\hline Land basis & 95 & 51.63 \\
\hline Others & 89 & 48.37 \\
\hline Canal lining up to the field & $\mathrm{N}=184$ & 100.00 \\
\hline Cemented & 90 & 48.91 \\
\hline Non cemented & 94 & 51.09 \\
\hline $\begin{array}{l}\text { Numbers of farmers using the } \\
\text { resource }\end{array}$ & $\mathrm{N}=184$ & 100.00 \\
\hline Greater than 40 & 91 & 49.46 \\
\hline Others & 93 & 50.54 \\
\hline $\begin{array}{l}\text { Alternative source of water } \\
\text { available }\end{array}$ & $\mathrm{N}=184$ & 100.00 \\
\hline Yes & 41 & 22.29 \\
\hline No & 143 & 77.71 \\
\hline Access to cooperatives & $\mathrm{N}=184$ & 100.00 \\
\hline Yes & 159 & 86.41 \\
\hline No & 25 & 13.59 \\
\hline Trainings received & $\mathrm{N}=184$ & 100.00 \\
\hline Yes & 61 & 33.15 \\
\hline No & 123 & 66.85 \\
\hline Social sanction & $\mathrm{N}=184$ & 100.00 \\
\hline Yes & 102 & 55.43 \\
\hline No & 82 & 44.57 \\
\hline
\end{tabular}

${ }^{1}$ Ethnic communities of Nepal 
User rights and duties are the basic norms or rules creating some sort of ownership to the irrigation either positive or negative. Well defined user rights and duties motivate the farmers in the proper management of the common pool resources. Poorly defined or not well-defined rights and duties in the randomness in the use of the resource.

Fine in monetary terms is also a significant socio-economic factor guiding the behavior of the users of a common-pool resource. Prevalence of monetary fine for some deeds out of the established social order or norms will bound the behavior of the individual in the correct path. Similarly, the presence of fine in money can control the behavior of the users of common resources within the proper manner.

There are different basis of labor mobilization of the water user groups for irrigation resource management as based on land, voluntarily, etc. the distribution of labor based on land being irrigated is the most scientific way of distribution as it is the most equitable approach. Farmers will be motivated to contribute more to the management of the resource if every user is contributing according to their land allocated for irrigation.

The lining of the canal of the field greatly alters the delivery of the water to the field which greatly affects the motivation of the farmers in the involvement of the management of the resource.

The number of farmers in a particular branch of the irrigation system greatly affects the behavior of the farmers in the management of their common-pool resource. The greater the number of the members, the greater will be the number of eyes watching the behavior of the farmers in the branch which will lead to a disciplined behavior among the farmers leading to greater motivation in the management of the resource.

The availability of the alternate source of irrigation other than the irrigation system under study also significantly affects the farmers' behavior in the management of the irrigation system under study. If they have an alternate source, they will be less careful or less obliged in the management of the irrigation system as they will have no compulsion to depend on it.

Social sanctions on improper behavior in the management of the irrigation system will compel the water user farmers to be on good behavior regarding the management of the irrigation system. The provision of social sanction will lead to an increase in the motivation for collective action for the management of the irrigation system.

The variable fine in money (FM), has a coefficient of 0.987 and a significance level of 0.020 which is less than 0.05 (Table 4). The variable number of farmers using the resource (NFUR), has a coefficient of 0.931 and a significance level of 0.025 which is less than 0.05 . The variable training received (RAT), has a coefficient of -1.261 and a significance level of 0.001 which is less than 0.01 .

The variable number of years of schooling of household head (NYSHHH), has a coefficient of 0.108 and a significance level of 0.013 which is less than 0.05 . The variable age of the household head (AgofHHH), has a coefficient of 0.023 and a significance level of 0.078 which is less than 0.1 .

Table 5: Factors motivating farmers for collective actions for the management of the irrigation system

\begin{tabular}{|c|c|c|c|c|c|}
\hline Variables & Coefficient. & $d y / d x$ & Std. Error & t-value & P-value \\
\hline$\overline{\mathrm{UR}}$ & -0.183 & -0.044 & 0.360 & -0.51 & 0.610 \\
\hline$\overline{\text { FM }}$ & $0.987 * *$ & 0.240 & 0.424 & 2.33 & 0.020 \\
\hline BLM & -0.242 & -0.059 & 0.359 & -0.68 & 0.500 \\
\hline $\mathrm{CL}$ & 0.163 & 0.040 & 0.344 & 0.47 & 0.636 \\
\hline NFUR & $0.931 * *$ & 0.223 & 0.416 & 2.24 & 0.025 \\
\hline ALTwsd & -0.622 & -0.153 & 0.428 & -1.45 & 0.146 \\
\hline Coop & 0.452 & 0.112 & 0.495 & 0.91 & 0.362 \\
\hline RAT & $-1.261 * * *$ & -0.304 & 0.383 & -3.29 & 0.001 \\
\hline SSd & -0.145 & -0.035 & 0.435 & -0.33 & 0.738 \\
\hline NYSHHH & $0.108 * *$ & 0.026 & 0.044 & 2.49 & 0.013 \\
\hline AgofHHH & $0.023 *$ & 0.006 & 0.013 & 1.76 & 0.078 \\
\hline Constant & $-2.415 * *$ & & 1.102 & -2.19 & 0.028 \\
\hline No. of observations & \multicolumn{5}{|l|}{184.000} \\
\hline Prob>chi2 & \multicolumn{5}{|l|}{0.000} \\
\hline Pseudo r-squared & \multicolumn{5}{|l|}{0.141} \\
\hline
\end{tabular}




\section{Discussions}

The presence of fine in monetary terms positively motivates the farmers for collective actions for the management of the irrigation system. The marginal effect of 0.240 suggests that the presence of monetary fine increases the chance of farmers being involved in collective action for the management of the irrigation system by 24 percent compared to those who think there is no fine in money terms for breaching any rule of the irrigation system.

The number of farmers in a branch of irrigation system being greater than 40, positively motivates farmers for collective actions for the management of the irrigation system. The presence of a large number of users will ensure better management of the resource so that everyone gets his amount of incentive from the source because if somebody turns irresponsible the large group can pressurize him or her to behave responsibly.

The farmers who have received agricultural training are less motivated in working together for the management of the irrigation system. This might be because the farmers who have received training regarding agriculture are demanding more water and are not satisfied with the amount of water they are receiving.

The farmers who have a higher level of education are motivated positively for the collective management of the irrigation system because an increase in education increases the civic sense of the person and they can better utilize their resources motivating for further better management and use (Meinzen-Dick 1997).

As the age of the household head increases, the farm family is positively motivated for the management of the irrigation system in a group because the older members of the family have since the transition from the rainfed farming to the irrigation farming and the efficiency of this transition motivates them for the better management of the irrigation system. The positive relation of age is in contrast to the statement that older peoples are more traditional and reluctant to change (Bhatta, Ishida and Sharma 2006).

\section{Conclusion}

Agricultural production and income are positively influenced by irrigation. The main findings of this research are that both farmers' socioeconomic characters and institutional characters of the irrigation system are the factors motivating farmers for collective actions for the management of the irrigation system. The difference in the characters of the household, attributes of the irrigation system and the perception of the farmers towards the institutional features of irrigation system has created a difference in the motivation among the farm families to get involved in the collective management of the irrigation system.
The results highlighted that farmers with a perception of the strict rule of fine in monetary terms tend to have a positive motivation for the group action in the management of the irrigation system. The rule of monetary fine for any irregular deeds by the farmers regarding the irrigation system will compel the farmers to behave in a disciplined way. The absence of this feature in a common pool resource will lead to the mismanagement and mishandling of the resource leading to the dispute in water use and allocation.

The results suggested that the presence of a large number of farmers i.e. 40 farmers/branch leads to positive motivation for the collective management of the irrigation system. The presence of a large number of farmers brings awareness regarding the use of an irrigation system as there is always someone watching on each other's activity so it turns pretty difficult to do wrong things and escape, leading to a welldisciplined behavior among the members of the irrigation system.

The years of schooling of the household head are also positively related to the collective action for the management of the irrigation system. An increase in education contributes to the overall development of a person leading to better social adaptability. Thus, more educated households are more motivated towards the collective management of the irrigation system.

The age of the household head is positively related to the collective action for the management of the irrigation system. The household heads with higher age can compare the present irrigated system of agriculture and the previous rainfed system and appreciate the positive impacts of irrigation system leading to the increased motivation in the collective management of the irrigation system.

Receiving of the agricultural training is negatively related to the collective action for the management of the irrigation system. Normally, progressive farmers are the farmers receiving agricultural training and these farmers may not be satisfied with the way the irrigation system is being utilized leading to their dissatisfaction in the management of the irrigation system collectively.

The results suggested that the rules of the irrigation system must be strict and implemented equally at all levels for better management of the irrigation system. Further, the members must be made aware about the benefits of the proper utilization of the irrigation system and the harms created by the mismanagement of the common resources.

\section{Authors' Contribution}

Kapil Khanal designed and conducted the research and he analyzed and interpreted the data. Prof. Dr. Kalika Bahadur Adhikari, Assoc. Prof. Dr. Shiva Chandra Dhakal and Assoc. Prof. Dr. Santosh Marahatta guided, advised, suggested, and provided constructive feedback to finalize this manuscript. 


\section{Conflict of Interest}

The authors declare that there is no conflict of interest.

\section{Acknowledgements}

The research was funded by University Grant Commission, Nepal. We would like to express our heartfelt gratitude to Post Graduate Committee of Agriculture and Forestry University, Nepal for their constructive and valuable suggestions.

\section{References}

AITC(2020) Agriculture and Livestock Diary 2077. Lalitpur, Nepal: Agriculture Information and Training Centre, Ministry of Agriculture and Livestock Development, Government of Nepal.

Bhatta KP, Ishida A, and Sharma R(2006) Performance of agencymanaged and farmer-managed irrigation systems: A comparative case study at Chitwan, Nepal. DOI: 10.1007/s10795-005-9001-8.

CBS(2013) Statistical year book of Nepal - 2013. 14th ed. Kathmandu, Nepal: Central Bureau of Statistics, National Planning Commission Secretariat, Government of Nepal.

Dhakal TR, Davidson B, and Farquharson B (2018) Factors affecting collective actions in farmer-managed irrigation systems of Nepal. Agriculture 8: 11.

Gautam U. Nepal (2012) Food Security, a Localized Institutional Irrigation Perspective on Public Irrigation Systems. Hydro Nepal: Journal of Water, Energy and Environment. 95-99.

Hussain I, Hanjra MA (2003) Does irrigation water matter for rural poverty alleviation? Evidence from South and South-East Asia. Water Policy 5: 429-442.

Meinzen-Dick R(1997) Farmer participation in irrigation: 20 years of experience and lessons for the future. Irrigation Drainage System 11: 103-118.

Muchara B, Ortmann G, Wale E, and Mudhara M (2014) Collective action and participation in irrigation water management: A case study of Mooi River Irrigation Scheme in KwaZulu-Natal Province, South Africa. Water SA 40:699.

Ostrom E(1990) Governing the Commons: The Evolution of Institutions for Collective Action. Alt JE, North DC (eds.).
Cambridge: Cambridge University Press.

Ostrom E, Gardner R, Walker J (1994) Rules, Games and Common-Pool Resources. 2006th ed. Greene Street Ann Arbor: The University of Michigan Press.

Pradhan P (2004) Farmer managed irrigation systems in Nepal at the crossroad. 8th Biennial Conference of the International Association for the Study of Common Property (IASCP) in Bloomington, Indiana, USA. May 31st - June 4th 1-14.

Pradhan P (2012) Revitalizing Irrigation Systems for Food Security: Vision and Approaches in Nepal Irrigation Systems. Hydro Nepal Journal of Water, Energy and Environment 44-49.

Rosegrant MW and Svendsen M (1993) Asian food production in the 1990s: Irrigation investment and management policy. Food Policy 13-32.

Sampath RK (1992) Issues in Irrigation Pricing in Developing Countries. World Development 20: 967-992.

Schoengold K and Zilberman D (2014) Water and Development : The Importance of Irrigation in Developing Countries.

Sijapati S and Paudel T (2010) Participatory Irrigation Management: Lessons to learn from FMIS. National Irrigation Seminar - Challenges in Irrigation Development and Management. Lalitpur: Department of Irrigation 11825 .

Sinyolo S, Mudhara M, and Wale E (2014) The impact of smallholder irrigation on household welfare: The case of Tugela Ferry irrigation scheme in KwaZulu-Natal, South Africa. Water SA 40: 145-56.

Thapa B and Scott CA (2019) Institutional strategies for adaptation to water stress in farmer-managed irrigation systems of Nepal. International Journal of the Commons 13: 892-908.

Vermillion DL (2001) Property Rights and Collective Action in the Devolution of Irrigation System Management. Workshop on Collective Action, Property Rights and Devolution of Natural Resource: 183-220.

Weirich P (2008) Utility Maximization Generalized. J Moral Philosophy 5: 282-99.

Yoder R (1994) Locally Managed Irrigation Systems: Essential Tasks and Implications for Assistance, Management Transfer and Turnover Programs. Colombo, Sri Lanka: International: IWMI. 